\title{
PENAMBAHAN TEPUNG PACI-PACI (LEUCAS LAVANDULAEFOLIA) PADA PAKAN TERHADAP MORTALITAS DAN GAMBARAN DARAH BENIH IKAN NILEM (OSTEOCHILUS HASSELTI) YANG DIUJI TANTANG MENGGUNAKAN BAKTERI AEROMONAS HYDROPHILA
}

\section{SUPPLEMENTATION OF PACI-PACI (LEUCAS LAVANDULAEFOLIA) ON FEED AGINST MORTALITY AND BLOOD PICTURE OF NILEM (OSTEOCHILUS HASSELTI) FRY THAT HAD BEEN CHALLENGED BY AEROMONAS HYDROPHILA BACTERIA}

\author{
Jonedhi $^{1 \mathrm{a}}$, Mulyana ${ }^{1}$, Muarif ${ }^{1}$ \\ ${ }^{1 a, 1}$ Jurusan Perikanan, Fakultas Pertanian, Universitas Djuanda Bogor \\ Jl. Tol. Ciawi No.1, Kotak Pos 35, Kode Pos 16720 \\ Korespondensi: Muarif, Email: muarif@unida.ac.id \\ (Diterima: 01-10-2015, Ditelaah: 07-10-2015, Disetujui: 19-10-2015)
}

\begin{abstract}
The research is aimed to know the effect of adding flour paci-paci (Leucas lavandulaefolia) to treated diseased nilem fry so that produced the highest of survival rate. The reasearch was done on January - September, 2015 at Fisheries Laboratory, Djuanda University, Bogor. The experiment design used in the study were completely randomized design with 4 treatments and 3 replications. The treatments were $4 \mathrm{~g}$ of paci-paci $/ \mathrm{kg}$ of feed, 6 $\mathrm{g}$ of paci-paci/kg of feed, and $8 \mathrm{~g}$ of paci-paci $/ \mathrm{kg}$ of feed. Nilem fry cultivated for 30 days, then nilem fry challenged test with Aeromonas hydrophila bacteria. The first challeged test with $10^{7}$ cell of Aeromonas hydrophila bacteria/mL on $35^{\text {th }}$ day and second challeged test with $10^{8}$ cell of Aeromonas hydrophila bacteria/mL on $38^{\text {th }}$ day. The results of research showed there was not significantly different between treatments for mortality and blood picture of nilem fry $(\mathrm{P}>0.05)$.
\end{abstract}

Key words : Nilem fry, paci-paci, Aeromonas hydrophila, mortality, blood picture

\begin{abstract}
ABSTRAK
Penelitian ini bertujuan untuk mengetahui pengaruh penambahan tepung paci-paci (Leucas lavandulaefolia) yang dicampurkan pada pakan terhadap mortalitas dan gambaran darah benih ikan nilem (Osteochilus hasselti) yang diuji tantang menggunakan bakteri Aeromonas hydrophila sehingga menghasilkan kelangsungan hidup yang lebih tinggi. Penelitian ini dilaksanakan pada bulan Januari 2015 sampai bulan September 2015 di Laboratorium Perikanan, Fakultas Pertanian, Universitas Djuanda Bogor. Ikan nilem dipelihara selama 30 hari kemudian dilakukan uji tantang dengan bakteri Aeromonas hydrophila dengan konsentrasi $10^{7} \mathrm{sel} / \mathrm{mL}$, dilakukan pengamatan sampai hari ke-35 dan kembali dilakukan uji tantang kedua dengan konsentrasi bakteri $10^{8} \mathrm{sel} / \mathrm{mL}$ dan dilakukan pengamatan sampai hari ke-38. Selama melakukan penelitian ikan diberi pakan dengan campuran tepung paci-paci dengan dosis $4 \mathrm{~g} / \mathrm{kg}, 6 \mathrm{~g} / \mathrm{kg}$, dan $8 \mathrm{~g} / \mathrm{kg}$. Hasil penelitian menunjukkan bahwa pemberian tepung paci-paci tidak memberikan pengaruh yang nyata $(\mathrm{P}>0,05)$ pada tingkat kelangsungan hidup benih ikan nilem, tetapi terdapat beberapa perbedaan pada kadar hemoglobin dan hematokit. Perlakuan tepung paci-paci dengan dosis 4 $\mathrm{g} / \mathrm{kg}$ memberikan gambaran darah yang cukup baik dibandingkan dengan perlakuan yang lain. Kata kunci : Ikan nilem, paci-paci, Aeromonas hydrophila, mortalitas, gambaran darah
\end{abstract}


Jonedhi et.al. 2015. Penambahan Tepung Paci-Paci (Leucas Lavandulaefolia) Pada Pakan Terhadap Moralitas dan Gambaran Darah Benih Ikan Nilem (Osteochilus Hasselti) Yang Diuji Tantang Menggunakan Bakteri Aeromonas Hydrophila. Jurnal Mina Sains 1(2): 57-66.

\section{PENDAHULUAN}

Ikan nilem (Osteochilus hasellti C.V) merupakan ikan air tawar yang termasuk ke dalam famili Cyprinidae yang bersifat herbivora dan habitat hidupnya menyebar di Asia Tenggara termasuk Indonesia. Permasalahan yang sering dihadapkan pada kegiatan pembenihan yaitu serangan organisme patogen salah satunya adalah bakteri yang dapat menimbulkan kerugian yang sangat besar bagi petani, meskipun pada kolam yang terawat dengan baik, wabah penyakit dan parasit ikan ini dapat menimbulkan kerugian besar karena sering menyebabkan kematian ikan secara masal. Salah satu bakteri yang sering menyerang ikan air tawar adalah Aeromonas hydrophila yang menyebabkan penyakit Motile Aeromonas Septicemia (MAS) atau penyakit bercak merah pada tubuh ikan. Untuk menghindari dampak negatif dari penggunaan kimia sintetis anorganik dalam pengendalian penyakit, perlu dicari alternatif pengobatan yang efektif mengendalikan penyakit, murah, aman terhadap manusia dan ramah lingkungan, salah satunya penggunaan fitofarmaka yaitu paci-paci (Leucas lavandolaefolia).
Berdasarkan penelitian yang telah dilakukan, paci-paci (Leucas lavandulaefolia) adalah salah satu fitofarmaka yang efektif mengatasi penyakit Motile Aeromonas Septicemia pada ikan (Abdullah, 2008; Sopiana, 2005; Utami, 2009).

Tujuan penelitian ini untuk mengetahui pengaruh penambahan tepung paci-paci (Leucas lavandulaefolia) yang dicampurkan pada pakan terhadap mortalitas dan gambaran darah benih ikan nilem (Osteochilus hasselti) yang diuji tantang menggunakan bakteri Aeromonas hydrophila.

\section{MATERI DAN METODE}

Penelitian ini akan dilaksanakan pada bulan Januari 2015 sampai dengan bulan September 2015 di Laboratorium Perikanan, Fakultas Pertanian, Universitas Djuanda Bogor.

Penelitian menggunakan rancangan percobaan berupa Rancangan Acak Lengkap (RAL) yang terdiri dari 4 perlakuan dengan 3 kali ulangan, masingmasing unit percobaan menggunakan 10 ekor benih ikan nilem. Perlakuan yang dilakukan adalah penambahan tepung pacipaci pada pakan buatan dengan konsentrasi 
berbeda. $\mathrm{K}$ perlakuan tanpa pemberian tepung paci-paci, A Pemeliharaan benih ikan nilem dengan pemberian tepung paci sebanyak $4 \mathrm{~g} / \mathrm{kg}$ pakan, B Pemeliharaan benih ikan nilem dengan pemberian tepung paci-paci sebanyak $6 \mathrm{~g} / \mathrm{kg}$ pakan, C Pemeliharaan benih ikan nilem dengan pemberian tepung paci-paci sebanyak 8 $\mathrm{g} / \mathrm{kg}$ pakan.

Peralatan yang digunakan dalam penelitian adalah akuarium sebanyak 12 unit dengan ukuran $30 \mathrm{~cm}$ x $30 \mathrm{~cm}$ x 30 $\mathrm{cm}$, timbangan digital ketelitian 0,1 gram, syringe $0,5 \mathrm{~mL}$, bahan penelitian meliputi ikan nilem ukuran $7 \mathrm{~cm}-8 \mathrm{~cm}$, isolat Aeromonas hydrophila, pakan komersil (27\%) dan tepung paci-paci.

Persiapan wadah dan ikan uji meliputi pertama akuarium dibersihkan dengan sabut dan dibilas dengan air kemudian diletakan berjajar dan secara acak. Sebelumnya air diendapkan lebih dulu dalam tandon selama 1 hari dan diaerasi. Kemudian akuarium diisi dengan air sampai ketinggian $20 \mathrm{~cm}$ dan dipasang aerasi. Ukuran benih ikan nilem yang digunakan 7-8 cm dan dimasukkan 10 ekor per akuarium. Ikan direndam dalam larutan garam 15 ppt selama kurang lebih 2 menit untuk mereduksi patogen eksternal yang melekat pada tubuh ikan dan mengadaptasikan ikan terhadap pakan dan lingkungannya yang baru selama 3 hari serta diberi pakan komersil (kadar protein $27 \%$ ) sebanyak 2 kali sehari yaitu secara ad libitum.

Bagian tanaman paci-paci (Leucas lavandulaefolia) yang diambil sebagai ekstrak kering adalah daun, batang dan akar kemudian dicuci dengan air bersih dan dikeringkan. Tujuan pengeringan mengurangi kadar air bahan sehingga lebih tahan terhadap aktivitas mikroba, mempermudah penentuan dosis dan meningkatkan konsentrasi zat aktif pada bahan obat (Yuliani, 1992). Setelah daun, batang dan akar kering kemudian dihaluskan dengan menggunakan blender lalu diayak dengan saringan sampai didapatkan bubuk halus.

Pemeliharaan selama 30 hari dan ikan diberi pakan sesuai perlakuan yang sudah dicampurkan ekstrak paci-paci (repeletting). Pemberian pakan dua kali/hari secara ad libitum. Setelah pemeliharaan 30 hari dilakukan uji tantang pertama pada hari ke-31 dengan konsentrasi bakteri Aeromonas hydrophila $10^{7} \mathrm{sel} / \mathrm{mL}$ dengan dosis penyuntikan 0,1 mL/ekor. Kemudian dilakukan pengamatan hingga uji tantang kedua untuk mengetahui jumlah ikan yang mati pada setiap wadah pemeliharaan. Uji tantang kedua pada hari ke-35 dengan dosis 10 kali lipat dari dosis uji tantang pertama dan dilakukan 
pengamatan seperti pada uji tantang pertama sampai hari ke-38.

Parameter yang diamati selama penelitian yaitu : Mortalitas, kualitas air, perhitungan sel darah merah, perhitungan sel darah putih, perhitungan kadar hemoglobin dan perhitungan kadar hematokrit.

\section{HASIL DAN PEMBAHASAN}

\section{Mortalitas}

Tabel 1 Mortalitas (\%) ikan nilem setelah uji tantang pertama

\begin{tabular}{|c|c|c|c|c|}
\hline \multirow[b]{2}{*}{ Ulangan } & \multicolumn{4}{|c|}{ Perlakuan } \\
\hline & $\begin{array}{l}\text { K } \\
\text { (tanpa } \\
\text { paci- } \\
\text { paci) }\end{array}$ & $\begin{array}{l}\mathrm{A} \\
\mathrm{g} / \mathrm{kg} \\
\text { pakan) }\end{array}$ & $\begin{array}{l}\text { B (6 } \\
\text { g/kg } \\
\text { pakan) }\end{array}$ & $\begin{array}{l}\mathrm{C} \quad(8 \\
\text { g/kg } \\
\text { pakan) }\end{array}$ \\
\hline 1 & 60 & 10 & 40 & 40 \\
\hline 2 & 20 & 10 & 70 & 40 \\
\hline 3 & 20 & 40 & 60 & 40 \\
\hline Rataan & $\begin{array}{l}33,3 \pm \\
23,1 \\
\end{array}$ & $\begin{array}{ll}20,0 & \pm \\
17,3 & \\
\end{array}$ & $\begin{array}{ll}56,7 & \pm \\
15,3 & \\
\end{array}$ & $\begin{array}{ll}40,0 & \pm \\
0,0\end{array}$ \\
\hline
\end{tabular}

Rataan mortalitas ikan nilem setelah uji tantang pertama paling tinggi pada perlakuan B yaitu sebesar 56,7\% dan paling rendah pada perlakuan A yaitu sebesar $20,00 \%$. Berdasarkan uji $\mathrm{F}$ analisis ragam ANOVA pada selang kepercayaan 95\% menunjukan tidak berbeda nyata terhadap mortalitas ikan nilem $(\mathrm{P}>0,05)$.

Tabel 2 Mortalitas (\%) ikan nilem setelah uji tantang kedua

\begin{tabular}{|l|l|l|l|l|}
\hline \multirow{2}{*}{ Ulangan } & \multicolumn{4}{|l|}{ Perlakuan } \\
\cline { 2 - 5 } & $\begin{array}{l}\text { K (tanpa } \\
\text { paci- } \\
\text { paci) }\end{array}$ & $\begin{array}{l}\mathbf{A}(\mathbf{4} \\
\text { g/kg } \\
\text { pakan) }\end{array}$ & $\begin{array}{l}\text { B } \\
\text { g/kg } \\
\text { pakan) }\end{array}$ & $\begin{array}{l}\text { C (8 g/kg } \\
\text { pakan) }\end{array}$ \\
\hline 1 & 20 & 30 & 40 & 40 \\
\hline 2 & 40 & 10 & 30 & 20 \\
\hline 3 & 10 & 20 & 20 & 20 \\
\hline
\end{tabular}

\begin{tabular}{|l|l|ll|ll|ll|}
\hline \multirow{2}{*}{ Rataan } & $23,3 \pm$ & 20,0 & $\mathbf{3 0 , 0}$ & \pm & 26,7 & \pm \\
& 15,0 & 10,0 & 10,0 & & 11,5 & \\
\hline
\end{tabular}

Rataan mortalitas ikan nilem setelah uji tantang kedua paling tinggi pada perlakuan B yaitu sebesar 30,0\% dan paling rendah terdapat pada perlakuan A yaitu sebesar 20,0\%. Berdasarkan uji $\mathrm{F}$ analisis ragam ANOVA pada selang kepercayaan 95\% tidak berbeda nyata terhadap mortalitas ikan nilem $(\mathrm{P}>0,05)$.

\section{Gambaran Darah}

\section{Sel Darah Merah (Eritrosit)}

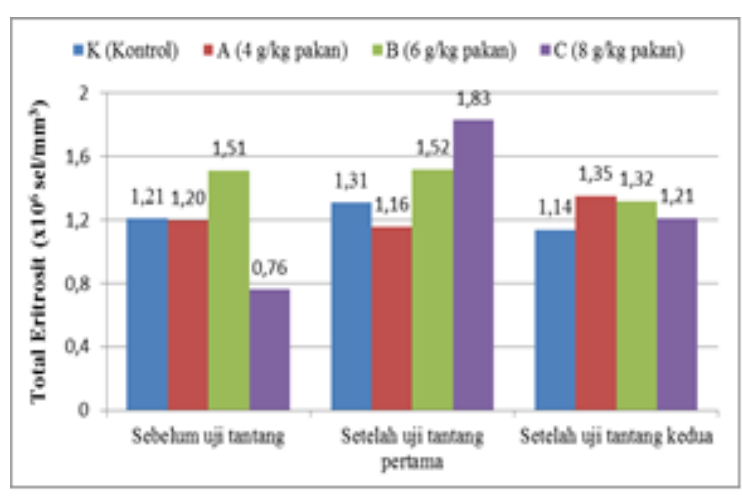

Gambar 1 Total Eritrosit $\left(\times 10^{6} \mathrm{sel} / \mathrm{mm}^{3}\right)$ ikan nilem

Rataan jumlah eritrosit sebelum uji tantang terbesar terdapat pada perlakuan B sebesar $1,51 \times 10^{6} \mathrm{sel} / \mathrm{mm}^{3}$ dan terkecil terdapat pada pada perlakuan $\mathrm{C}$ sebesar $0,76 \times 10^{6} \mathrm{sel} / \mathrm{mm}^{3}$. Uji tantang pertama nilai terbesar terdapat pada perlakuan $\mathrm{C}$ $1,83 \times 10^{6} \mathrm{sel} / \mathrm{mm}^{3}$ dan nilai terkecil pada perlakuan A sebesar $1,16 \times 10^{6} \mathrm{sel} / \mathrm{mm}^{3}$. Kemudian setelah uji tantang kedua nilai terbesar terdapat pada perlakuan A sebesar $1,35 \times 10^{6} \mathrm{sel} / \mathrm{mm}^{3}$ dan nilai terkecil pada perlakuan $\mathrm{K}$ sebesar $1,14 \times 10^{6} \mathrm{sel} / \mathrm{mm}^{3}$. 
Berdasarkan uji $\mathrm{F}$ analisis ragam ANOVA pada selang kepercayaan 95\%, diperoleh hasil bahwa pemberian ekstrak paci-paci sebelum uji tantang memberikan pengaruh pada perlakuan $\mathrm{A}, \mathrm{B}$, dan $\mathrm{C}$ terhadap Kontrol dimana $(\mathrm{P}<0,05)$ selanjutnya untuk uji tantang pertama dan kedua perlakuan A, B, C dan Kontrol tidak berbeda nyata terhadap eritrosit ikan nilem setelah uji tantang pertama dan uji tantang kedua $(\mathrm{P}>0,05)$.

\section{Sel Darah Putih (Leukosit)}

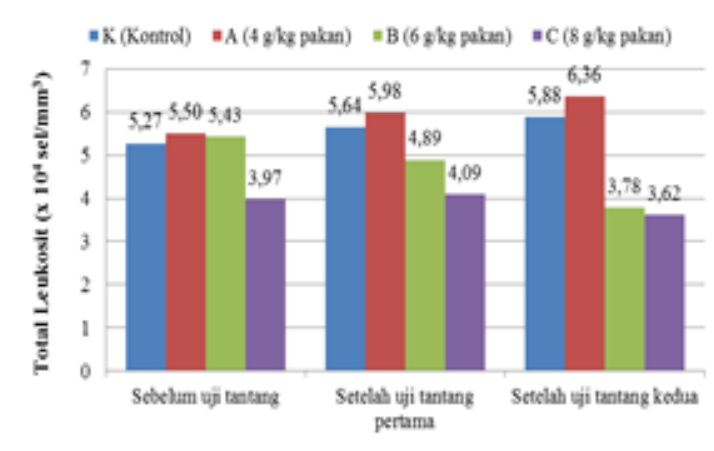

Gambar 2 Total Leukosit $\times 10^{4} \mathrm{sel} / \mathrm{mm}^{3}$ ) ikan nilem

Dari Gambar 2 dapat dilihat bahwa sebelum uji tantang nilai leukosit terbesar terdapat pada perlakuan A dan terkecil terdapat pada pada perlakuan C. Pada uji tantang pertama nilai terbesar terdapat pada perlakuan A dan terkecil pada perlakuan C. Kemudian setelah uji tantang kedua nilai terbesar terdapat pada perlakuan A dan terkecil pada perlakuan C. Berdasarkan uji $\mathrm{F}$ analisis ragam ANOVA pada selang kepercayaan $95 \%$ tidak berbeda nyata $(\mathrm{P}>0,05)$.

\section{Kadar Hemoglobin (Hb)}

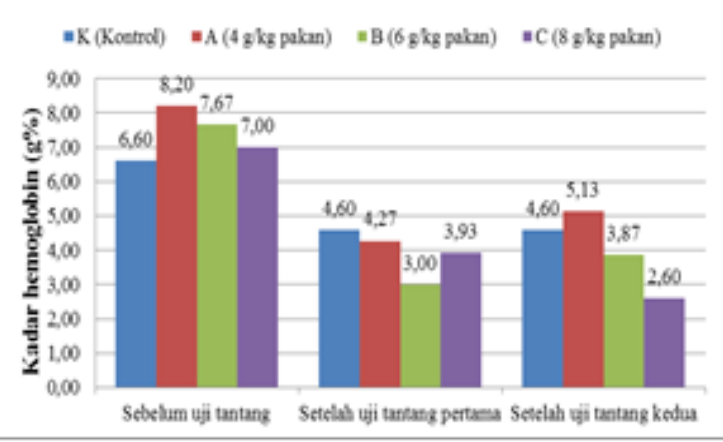

Gambar 3 Kadar hemoglobin (g\%) ikan nilem

Berdasarkan uji $\mathrm{F}$ analisis ragam ANOVA pada selang kepercayaan 95\% tidak berbeda nyata terhadap hemoglobin ikan nilem $(\mathrm{P}>0,05)$.

Dari Gambar 3 dapat dilihat bahwa sebelum uji tantang nilai hemoglobin terbesar terdapat pada perlakuan A dan terkecil terdapat pada pada perlakuan $\mathrm{K}$. Pada uji tantang pertama nilai terbesar terdapat pada perlakuan Kdan terkecil pada perlakuan B. Kemudian setelah uji tantang kedua nilai terbesar terdapat pada perlakuan A dan terkecil pada perlakuan C.

\section{Kadar Hematrokit (Ht)}

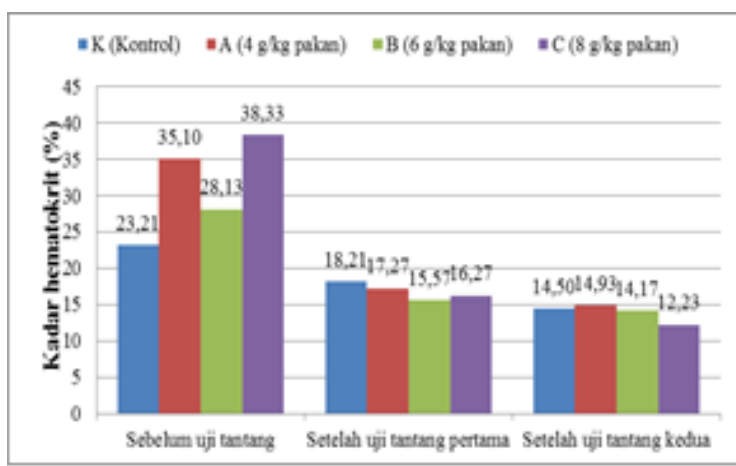

Gambar 4 Kadar hematokrit (\%) ikan nilem

Dari Gambar 4 dapat dilihat bahwa sebelum uji tantang nilai hematokrit terbesar terdapat pada perlakuan $\mathrm{C}$ dan 
paling kecil terdapat pada pada perlakuan K. Pada uji tantang pertama nilai terbesar terdapat pada perlakuan $\mathrm{K}$ dan nilai terkecil pada perlakuan B. Kemudian setelah uji tantang kedua nilai terbesar terdapat pada perlakuan A dan nilai terkecil pada perlakuan C. Berdasarkan uji $\mathrm{F}$ analisis ragam ANOVA pada selang kepercayaan 95\% tidak berbeda nyata terhadap hematokrit ikan nilem $(\mathrm{P}>0,05)$.

\section{Pembahasan}

Hasil mortalitas menunjukan bahwa pemberian tepung paci-paci pada pakan tidak berpengaruh nyata $(\mathrm{P}>0,05)$ terhadap tingkat mortalitas ikan nilem yang sebelumnya sudah diinfeksi dengan bakteri Aeromonas hydrophila. Mortalitas yang rendah pada perlakuan A ini disebabkan daya tubuh dan jumlah total leukosit (Gambar 1) benih ikan nilem meningkat. Peningkatan jumlah total leukosit ini berperan sebagai pertahanan non-spesifik dan adanya peningkatan indeks fagositosis. Menurut Anderson (1992) leukosit merupakan salah satu komponen darah yang berfungsi sebagai pertahanan nonspesifik yang akan melokalisasi dan mengeliminir pathogen melalui fagositosis.

Pemberian tepung paci-paci dengan dosis yang lebih besar memberikan pengaruh yang sebaliknya dengan tingkat kematian yang tinggi dibandingkan dengan kontrol. Mortalitas yang tinggi disebabkan daya tubuh benih ikan nilem menurun. Dari hasil pengamatan benih ikan nilem terlihat stress pasca penyuntikan bakteri Aeromonas hydrohila dan respon nafsu makannya menurun. Sedangkan dari hasil pengamatan jumlah total leukositnya menurun dan pengamatan gejala klinis yang terlihat pasca penyuntikan ikan menggalami peradangan dan tukak pada tubuhnya.

Dari hasil pengamatan pasca penyuntikan bakteri Aeromonas hydrophila gejala klinis yang muncul yaitu ikan telihat diam dan stress, pergerakannya tidak teratur, berenang di dasar akuarium, terlihat matanya agak menonjol keluar, berenang dengan posisi badan terbalik miring, berkumpul di sekitar aerasi dan menggosok-gosokkan tubuhnya pada dinding akuarium. Gejala ini terlihat merata pada semua benih nilem yang dilakukan infeksi buatan (penyuntikan). Gejala lain yang muncul yaitu nafsu makannya menurun. Menurut Setiaji (2009) menegaskan bahwa ikan yang disuntik dengan bakteri Aeromonas hydophila secara intramuscular akan mengalami hilangnya nafsu makan dan perubahan patogenitas.

Selanjutnnya pada hari kelima pasca uji tantang pertama dilakukan kembali uji 
tantang kedua dengan kepadatan bakteri 10 kali lebih besar dari pada uji tantang pertama dengan kepadatan bakteri $10^{8}$ sel/mL. Hal ini diduga karena sistem imun pada ikan sudah mengenal bakteri dengan kepadatan sebelumnya jadi agar uji tantang kedua lebih efektif kemudian dilakukan peningkatan kepadatan bakteri, warna merah yang muncul pada uji tantang pertama berubah menjadi tukak, kemudian tukak tersebut semakin berkurang selang beberapa hari pasca uji tantang kedua. Hal ini menandakan bahwa pemberian tepung paci-paci memberikan pengaruh terhadap respon imun pada ikan karena pada pacipaci terdapat senyawa-senyawa yang dapat meningkatkan sistem imun seperti minyak atsiri dan flavonoid (Mukherjee et al. 1997a), kandungan dari senyawa tersebut berperan sebagai wound healing activity sehingga mampu mempercepat penyembuhan luka (Mukherjee et al. 1997b) hal itu terlihat dari perubahan fisik ikan yang mengalami nekrosis dan tukak terlepas dari tubuh ikan uji pada saat penelitian.

\section{Gambaran Darah}

Dari hasil penelitian didapatkan bahwa kadar eritrosit ikan nilem memiliki nilai yang bervariatif pada saat penelitian sebelum uji tantang, setelah uji tantang pertama dan setelah uji tantang kedua. Hasil penelitian sebelum uji tantang dengan bakteri A. hydrophila nilai eritrosit yang tertinggi didapatkan pada perlakuan B sebesar $1,51 \times 10^{6} \mathrm{sel} / \mathrm{mm}^{3}$ dan terendah pada perlakuan $\mathrm{C}$ sebesar $0,76 \times 10^{6}$ $\mathrm{sel} / \mathrm{mm}^{3}$. Setelah uji tantang pertama nilai eritrosit tertinggi pada perlakuan $\mathrm{C}$ sebesar $1,83 \times 10^{6} \mathrm{sel} / \mathrm{mm}^{3}$ dan terendah pada perlakuan A sebesar $1,16 \times 10^{6} \mathrm{sel} / \mathrm{mm}^{3}$. Selanjutnya setelah uji tantang kedua nilai eritrosit tertinggi pada perlakuan A sebesar $1,35 \times 10^{6} \mathrm{sel} / \mathrm{mm}^{3}$ dan terendah pada perlakuan $\mathrm{K}$ sebesar $1,14 \times 10^{6} \mathrm{sel} / \mathrm{mm}^{3}$. Pada ikan yang normal, jumlah sel darah merah berkisar antara 1,05-3,00 × $10^{6}$ $\mathrm{sel} / \mathrm{mm}^{3}$ (Roberts, 1978). Jumlah sel darah merah (eritrosit) ikan nilem normal berkisar $5,35 \times 10^{6} \mathrm{sel} / \mathrm{mm}^{3}$ (Andayani et al. 2014). Rendahnya jumlah sel darah merah (eritrosit) menandakan ikan dalam keadaan stress (Wedemeyer dan Yasutake, 1977; Nabib dan Pasaribu, 1989).

Menurut Angka (1985) ikan yang sehat memiliki sel darah putih yang lebih rendah dibandingkan dengan ikan yang sakit. Menurut Moyle dan Cech (1988), leukosit berfungsi sebagai sistem pertahanan tubuh ikan yang bereaksi terhadap gangguan dari luar termasuk infeksi patogen. Perkembangan rataan sel darah putih benih nilem yang diamati selama penelitian pada Gambar 2 memperlihatkan rataan total leukosit sebelum uji tantang pada perlakuan A, B, 
dan $\mathrm{K}$ lebih tinggi dibandingkan dengan perlakuan C. Setelah dilakukan uji tantang pertama terjadi perubahan total leukosit pada setiap perlakuan pada perlakuan $\mathrm{K}, \mathrm{A}$, dan B rataan total leukosit meningkat, sedangkan perlakuan $\mathrm{C}$ menurun. Rataan total leukosit setelah uji tantang kedua memperlihatkan peningkatan rataan total leukosit pada perlakuan $\mathrm{K}$ dan $\mathrm{A}$, sedangkan perlakuan $\mathrm{B}$ dan $\mathrm{C}$ terjadi penurunan.

Peningkatan ini menandakan bahwa ikan merespon bakteri yang diinjeksikan kedalam tubuhnya. Dari hasil yang didapatkan dari pengamatan kisaran leukosit yang diperoleh berkisar antara $3,5 \times 10^{4}-6,5 \times 10^{4} \mathrm{sel} / \mathrm{mm}^{3}$. Jumlah sel darah putih pada ikan berkisar antara 20.000-150.000 sel $/ \mathrm{mm}^{3}$ darah (Marthen, 2005). Secara keseluruhan menurut data yang diperoleh nilai leukosit masih dalam kisaran normal.

Hasil pengukuran kadar hemoglobin $\mathrm{Hb}$ pada masing-masing perlakuan menunjukkan nilai yang fluktuatif (Gambar 3). Sebelum uji tantang kadar $\mathrm{Hb}$ tertinggi pada perlakuan A sebesar 8,20 g\% dan terendah pada perlakuan $\mathrm{K}$ sebesar 6,60 g\%. Setelah uji tantang pertama kadar $\mathrm{Hb}$ yang tinggi pada perlakuan $\mathrm{K}$ sebesar 4,60 $\mathrm{g} \%$ dan terendah pada perlakuan B sebesar 3,00 g\% dan setelah uji tantang kedua nilai
$\mathrm{Hb}$ yang tinggi pada perlakuan A sebesar $5,13 \mathrm{~g} \%$ dan terendah pada perlakuan C sebesar 2,60 g\%. Kadar $\mathrm{Hb}$ sebelum uji tantang masih berada pada kisaran normal (mengacu pada $\mathrm{Hb}$ ikan mas sebesar 6-10 g\%). Setelah penyuntikan bakteri $A$. hydrophila kadar $\mathrm{Hb}$ pada setiap perlakuan setelah uji tantang pertama dan kedua cenderung menurun dibawah kisaran normal diduga hal ini disebabkan kadar oksigen dalam darah menurun. Banyak faktor yang mempengaruhi rendahnya kadar hemoglobin menurut Dellman and Brown (1989) mengatakan kadar hemoglobin dibawah kisaran normal mengindikasikan rendahnya kandungan protein pakan, defisiensi vitamin dan kualitas air buruk atau ikan mandapat infeksi. Sehingga dapat diduga bahwa rendahnya nilai hemoglobin akibat ikan mendapat infeksi.

Dari hasil yang diperoleh kadar hematokrit (Gambar 4) ikan nilem memiliki nilai yang yang berbeda dari setiap perlakuan. Nilai hematokrit sebelum uji tantang tertinggi pada perlakuan $\mathrm{C}$ sebesar $38,33 \%$ dan terendah pada perlakuan $\mathrm{K}$ sebesar 23,21\%. Setelah uji tantang pertama kadar yang tinggi pada perlakuan $\mathrm{K}$ sebesar $18,21 \%$ dan terendah pada perlakuan B sebesar 15,57\% dan setelah uji tantang kedua kadar hematokrit tertinggi 
pada perlakuan A sebesar 14,93\% dan terendah pada perlakuan $\mathrm{C}$ sebesar $12,23 \%$. Kadar hematokrit benih ikan nilem sebelum uji tantang masih berada dalam kisaran nilai hematokrit normal pada ikan. Menurut Svobodova dan Vyukusova melaporkan bahwa kadar hematokrit pada ikan mas berkisar antara $28-40 \%$. Setelah uji tantang pertama dan kedua nilai hematokrit benih ikan nilem menggalami penurunan hal ini diduga karena ikan mengalami anemia dan stress karena terinfeksi oleh bakteri A. hydrophila. Wedemeyer dan Yasutake menyatakan menurunnya kadar hematokrit dapat dijadikan petunjuk mengenai rendahnya kandungan protein, defisien vitamin atau ikan mendapatkan infeksi.

Kisaran suhu pada saat pengamatan berkisar antara $26-27{ }^{\circ} \mathrm{C}$. Oksigen terlarut adalah jumlah $\mathrm{mg} / \mathrm{L}$ gas oksigen yang terlarut dalam air. Kadar oksigen terlarut sangat berhubungan dengan peningkatan suhu. Menurut Effendi (2003) peningkatan suhu sebesar $1^{\circ} \mathrm{C}$ akan meningkatkan konsumsi oksigen sekitar 10\%, kisaran oksigen yang didapatkan dari hasil pengamatan adalah 4,0 - 4,5 ppm. pH merupakan parameter aktivitas ion hidrogen $(\mathrm{H}+)$ dalam suatu larutan yang dinyatakan dengan asam atau basa. Mackereth et al (1989) menyatakan bahwa $\mathrm{pH}$ juga berkaitan erat dengan karbondioksida dan alkalinitas. Nilai $\mathrm{pH}$ amat mempengaruhi proses bio-kimiawi perairan misalnya proses nitrifikasi akan berakhir jika $\mathrm{pH}$ rendah. $\mathrm{pH}$ yang paling baik berkisar antara 6.5-8.5 (Rachmiwati, 2008). Dari hasil pengamatan nilai $\mathrm{pH}$ berkisar antara $6,7-8,0$.

\section{KESIMPULAN}

Dari hasil yang diperoleh menunjukkan bahwa tepung paci-paci yang dicampurkan lewat pakan tidak memberikan pengaruh nyata $(\mathrm{P}>0,05)$ terhadap penyembuhan pada ikan nilem yang diinfeksi bakteri Aeromonas hydrophila.

\section{DAFTAR PUSTAKA}

Andayani S, Marsoedi, Sanoesi E, Wilujeng AE, Suprastiani H. 2014. Profil Hematologis Beberapa Spesies Ikan Air Tawar Budidaya. [Jurnal]. Fakultas Sains dan Teknologi UIN Maliki Malang.

Anderson DP. 1992. Immunostimulants, Adjuvants And Vaccine Carriers In Fish. Application To Aquaculture Annual Rev. Of Fish Disease.

Angka SL, Wongkar GT, Karwani W. 1985. Blood Picture and Bacteria Isolated from Ulcered and Crooked Back Clarias Batrachus. Biotrop Special Publishing (2). Biotrop, Bogor.

Dellman HD, Brown EM. 1989. Buku Teks Histologi Veteriner 1. Hartono (Penerjemah). Jakarta : UI Press. 
Effendi H. 2003. Kualitas Air bagi Pengelolaan Sumber Daya dan Lingkungan Perairan. Cetakan Kelima. Yogyakarta. Kanisius

Moyle PB, Cech JJ. 1988. Fishes An Introduction to Ichthyology. Second Adition. New Jersey : Prentice Hall

Mukherjee PK, Saha K, Saha BP, Murugesan, Pal M. 1997a. Studies on in vivo antitussive activity of Leucas lavandulaefolia using a cough model induced by sulfur dioxide gas in mice. J Ethnopharmacology.

Mukherjee PK, Saha K, Saha BP, Das J, Pal M. 1997b. Wound Healing Activity of Leucas lavandulaefolia. $J$ Ethnopharmacology.

Nabib R, Pasaribu FH. 1989. Patologi dan Penyakit Ikan, Departemen Pendidikan dan Kebudayaan. Direktorat Jendral Pendidikan Tinggi. Pusat Antar Universitas Bioteknologi, Institut Pertanian Bogor. UPT Produksi Media Informasi LSI-IPB. Bogor.

Roberts RJ, Richards RH. 1978. The Bacteriology of Teolost in Fish Pathology. Roberts RJ,editor. Bailliere Tindal Book Publ, London.
Setiaji A. 2009. Efektifitas Ekstrak Daun Pepaya Carica papaya L. Untuk Pencegahan Dan Pengobatan Ikan Lele Dumbo Clarias sp Yang Diinfeksi Bakteri Aeromonas hydrophila. [Skripsi]. Departemen Budidaya Perairan, FPIK IPB. Bogor.

Svobodova Z, Vyukusova B. 1991. Diagnostic, Prevention and Therapy of Fish Disease and Intoxication. Research Institute of Fish Culture and Hydro biology Vodnany Czechoslovakia. Tersedia pada: http//www.fao.org/fi/website/firetrive action $\cdot$ do?dom=topic \&fid=16064\&la $\mathrm{ng}=\mathrm{en}$.

Wedemeyer GA, Yasutake WT. 1977. Clinical Methods for the Assessment of the Effect Environment Stress on the Fish Health. Technical Papers of the US Fish and Wildlife Service. US Depart of the Interior Fish and Wildlife Service.

Yuliani S. 1992. Teknik Pengeringan dan Penyimpanan Ekstrak Obat. Prosiding Forum Komunikasi, Ilmiah Hasil Penelitian Plasma Nutfah dan Budidaya Tanaman Obat Bogor. Bogor. 